\title{
Criminalizing HIV transmission may be a mistake
}

$\mathrm{T}$ here is no way to defend the actions of individuals who transmit HIV to others while knowing that they themselves are HIV-infected. This is especially true if these transmitters have lied to their partners about their HIV status and/or refused to use a condom during the sex act. Under current Canadian law, such individuals, if charged with sexual assault, should arguably be convicted.

Although it is counterintuitive to argue against the prosecution of such people, it is important to understand that there may be negative consequences if these cases are brought to trial.

The potential to be charged with wilful HIV transmission may be a significant deterrent to being tested for HIV infection. After all, individuals who do not know that they are HIV-positive cannot logically be accused of its transmission. The consequence may be a failure to identify as many HIV-positive people as possible and higher rates of HIV spread. Studies have shown that individuals who are informed that they are HIV positive will commonly desist from high-risk sexual practices, but may not do so if they are unaware of their own status. This is important, since as many as $50 \%$ of all new HIV transmissions are attributable to people who are only recently infected. ${ }^{1,2}$

If testing is delayed, many HIVinfected persons may not be diagnosed until at least several years after infection, thus giving the virus an opportunity to cause significant, often irreversible, damage to the immune system. This may sometimes result in lifethreatening infections and cancers that might have been avoided had antiretroviral therapy started sooner.

Earlier initiation of antiretroviral therapy also lowers the amount of virus in both blood and sexual fluids, thereby rendering people far less infectious for their sexual contacts. ${ }^{3}$ Thus, appropriate use of anti-HIV drugs will not only improve the health of infected persons, but may also have benefits for HIV spread and public health.

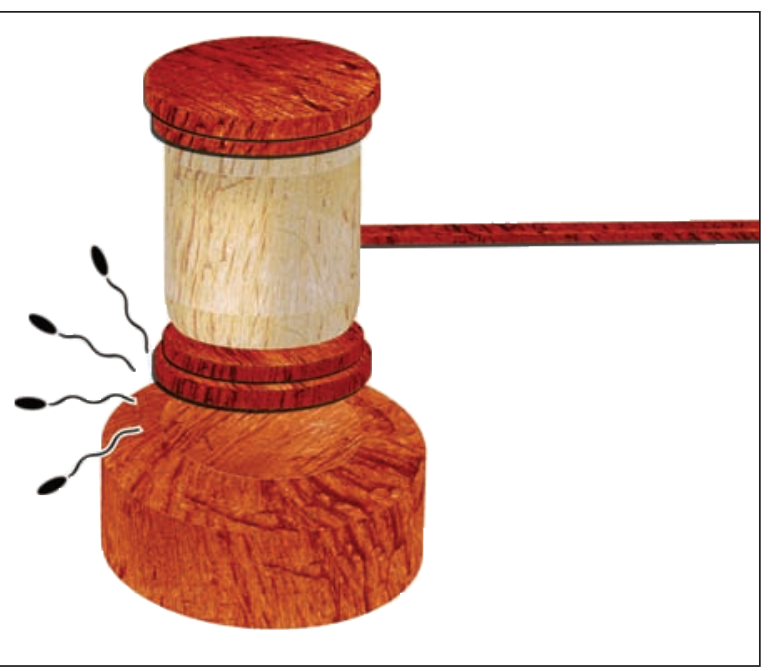

In almost all cases of prosecution of HIV transmission, defense lawyers have argued that HIV may not cause AIDS, as was recently heard in a case in Australia. The press coverage of these cases has often created confusion as to the harmful nature of HIV and has given HIV denialists a platform from which to promulgate their views (www.aidstruth.org).

We should also recognize that there is no consistency in how we view the wilful transmission of sexually transmitted diseases, the exception being HIV. We do not prosecute individuals who may knowingly transmit gonorrhea, chlamydia or syphilis. Nor do we prosecute individuals who may have transmitted hepatitis $\mathrm{C}$ virus, which can often cause fatal disease, or human papillomavirus, which causes cervical cancer.

How can society resolve this problem, while not, in effect, encouraging sexual promiscuity and risk behaviour?

First, we need to recognize that the current criminalization of HIV transmission probably acts as a deterrent to HIV testing by, in effect, promoting HIV transmission by people who do not know or don't want to know that they are infected.

We also need to accept that having sexual relations involves a personal responsibility to know one's partner on much more than a superficial level.

If the evidence in cases of wilful HIV transmission is upheld in court, this will substantiate that the people charged are irresponsible. But let's also recognize that the risk of being accused of the "crime" of HIV transmission, alongside the stigma of being identified as HIV positive, constitute significant deterrents for many people who may simply prefer not to know their status.

Sympathy for the unwitting, unfortunate victims of HIV transmissions and a desire for revenge should not guide the formulation of public policy on this issue.

\section{Mark A. Wainberg PhD \\ Director \\ McGill University AIDS Centre \\ Jewish General Hospital \\ Montréal, Que.}

\section{REFERENCES}

1. Wawer MJ, Gray RH, Sewankambo NK, et al. Rates of HIV-1 transmission per coital act, by stage of HIV-1 infection, in Rakai, Uganda. J Infect Dis, 2005;191:1403-9.

2. Brenner BG, Roger M, Routy JP, et al. High rates of forward transmission events after acute/early HIV-1 infection. J Infect Dis 2007;195:951-9.

3. Quinn TC, Wawer MJ, Sewankambo N, et al. Viral load and heterosexual transmission of human immunodeficiency virus type 1 . Rakai Project Study Group. N Engl J Med 2000;342:921-9.

Research performed in Dr. Wainberg's laboratory is supported by the Canadian Institutes of Health Research.

Have you got an opinion about this article? Post your views at www.cmaj.ca. Potential Salon contributors are welcome to send a query to salon@cmaj.ca. 